\title{
Menelisik Strategi Pemasaran Rumah Sakit Menggunakan Market Based-Management
}

\section{Noveri Maulana}

Sekolah Tinggi Manajemen PPM

nvr@ppm-manajemen.ac.id

\begin{abstract}
This research is aimed to develop a strategic marketing plan for a Heart \& Cardiovascular Hospital in Jakarta coded Hospital XYZ. The strategic framework in this study is using marketbased management concept which is rarely used in the healthcare business development. Mix method analysis are implemented in this study which combining the survey, interview, field observation, and documents review in the process of data collection method. Results show that in marketing attractiveness index, the market of cardiovascular healthcare system is attractive with score 61.5, meanwhile the competitive position of the Hospital XYZ is 59.8. The portfolio matrix which is implemented shows that offensive strategy is more suitable for the strategic marketing plan of the hospital for the upcoming years. There are two alternatives of offensive strategy which are 'Growth Market Share' strategy and 'Expand Market Demand' Strategy. Those strategies could be implemented by improving the quality of sales force, initiating the Corporate and Marketing Communication, and also expanding to B2B market by forcing Push and Pull Communication Strategy.
\end{abstract}

Keywords: Hospital Marketing; Strategic Marketing for Hospital; Healthcare Marketing; market-based management; Competitive Matrix; Market Attractiveness

\begin{abstract}
ABSTRAK
Penelitian ini bertujuan untuk membuat strategi pemasaran salah satu rumah sakit jantung swasta nasional (RS XYZ) di Jakarta dengan pendekatan Market-based Management. Dalam proses pengumpulan dan analisis data, penulis menggunakan mix method approach yang memadukan pendekatan kualitatif dan kuantitatif melalui survey kuesioner, wawancara, observasi lapangan, dan studi literatur. Hasil penelitian menunjukkan bahwa potensi bisnis kesehatan jantung di Jakarta masih sangat tinggi dengan nilai market attractiveness 61.5 dan nilai competitive position Rumah Sakit XYZ tersebut adalah sebesar 59.8. Hasil portfolio analysis menunjukkan bahwa strategi pilihan yang bisa diimplementasikan oleh rumah sakit XYZ ialah offensive strategy dengan pilihan pada core strategy IA: grow market share, dan core strategy ID: expand market demand. Strategi pemasaran ini memberi rekomendasi kepada Rumah Sakit XYZ untuk mengintegrasikan segmen pasar business to business (B2B) dan business to consumer (B2C) dengan membentuk marketing sales forces, menerapkan push dan pull communication, serta membentuk divisi corporate communication.
\end{abstract}

Keywords: Pemasaran Rumah Sakit; Strategi Pemasaran; Manajemen Rumah Sakit; Market-based Management; Competitive Position; Market Attractiveness 


\section{PENDAHULUAN}

Selain mengemban misi kemanusian, rumah sakit juga menjalankan misi bisnis untuk mendapatkan profit dan memastikan keberlanjutan usahanya. Sebagai sebuah entitas bisnis, rumah sakit juga perlu dikelola secara professional dengan memenuhi kaidah manajemen bisnis, namun tetap tunduk pada etika dan aturan profesi. Oleh karena itu, pengelolaan manajemen bisnis rumah sakit harus mampu memadukan dua kepentingan tersebut. Beberapa penelitian telah mengadopsi berbagai pendekatan dalam menyusun perencanaan strategis rumah sakit. Baik itu penelitian terkait strategi investasi dan manajemen risiko rumah sakit (Dewi \& Sri Darma, 2019), strategi pengelolaan program jaminan kesehatan nasional di rumah sakit (Kosala \& Maradona, 2019; Vikandi et al., 2019), penyusunan strategi rumah sakit dengan analisis SWOT (Karmawan, 2016; Puspitasari et al., 2016; Subianto, 2016; Setyawati dan Darma, 2018), penyusunan strategi rumah sakit dengan QSPM Matriks (Burhanudin, 2019), dan penyusunan strategi pemasaran rumah sakit dengan berbagai pendekatan (Hariyanti \& Rosyidah, 2013; Pandiangan \& Damanik, 2019; Puspitasari et al., 2016).

Namun, dari banyak penelitian terkait penyusunan strategi pemasaran rumah sakit, masih sedikit penelitian yang menggunakan kerangka analisis pasar sebagai acuan dalam menyusun rencana pemasaran. Penelitian ini berupaya mengisi keterbatasan literatur dan kajian di bidang itu. Menggunakan pendekatan market-based management, peneliti ingin memberikan perspektif baru dalam penyusunan strategi pemasaran di rumah sakit dengan adaptasi dari kerangka manajemen bisnis komersial.

Rumah sakit adalah institusi pelayanan kesehatan yang menyelenggarakan pelayanan kesehatan perorangan secara paripurna yang menyediakan pelayanan rawat inap, rawat jalan, dan gawat darurat. Rumah sakit merupakan salah satu dari sarana kesehatan yang juga merupakan tempat menyelenggarakan upaya kesehatan yaitu setiap kegiatan untuk memelihara dan meningkatkan kesehatan serta bertujuan untuk mewujudkan derajat kesehatan yang optimal bagi masyarakat (UU No 44, 2009). Upaya kesehatan dilakukan dengan pendekatan pemeliharaan, peningkatan kesehatan (promotif), pencegahan penyakit (preventif), penyembuhan penyakit (kuratif) dan pemulihan (rehabilitatif) yang dilaksanakan secara serasi dan terpadu serta berkesinambungan.

Sebagai sebuah entitas bisnis yang juga mengemban misi sosial, maka kegiatan bisnis rumah sakit diatur secara ketat melalui berbagai regulasi dari pemerintah (Karmawan, 2016; Pandiangan \& Damanik, 2019; Puspitasari et al., 2016). Beberapa aturan, undang-undang, kode etik, dan kebijakan yang berkaitan dengan proses bisnis rumah sakit setidaknya tertuang pada 
Undang-Undang Republik Indonesia Nomor 44 Tahun 2009 tentang rumah sakit, Peraturan Menteri Kesehatan (Permenkes) nomor 1787 tahun 2010 tentang Iklan dan Publikasi Pelayanan Kesehatan, Kode Etik Rumah Sakit Indonesia (KODERSI), dan Aturan Etika Promosi Rumah Sakit dari Persatuan Rumah Sakit Seluruh Indonesia (PERSI).

Akan tetapi, sebagai sebuah entitas bisnis, rumah sakit juga harus melakukan pengelolaan manajemen yang baik dan berkesinambungan (Vikandi et al., 2019). Kepiawaian manajemen dalam mengelola misis sosial dan tujuan bisnis rumah sakit menjadi sebuah tantangan bagi keberlanjutan rumah sakit itu sendiri. Oleh karena itu, manajemen rumah sakit harus mampu menerapkan prinsip manajemen yang baik untuk pengelolaan bisnisnya. Bahkan ketika dukungan dana pemerintah melalui program BPJS pun juga tersedia, rumah sakit tetap mendapat tantangan dalam aspek keberlanjutan bisnisnya (Kosala \& Maradona, 2019). Hal ini harus menjadi perhatian serius dari para pimpinan.

Proses pemasaran merupakan salah satu hal yang paling menantang dalam aktivitas manajemen rumah sakit. Sebagai penerapan misi preventif, kegiatan pemasaran rumah sakit juga harus mengikuti aturan dan kode etik profesi yang harus senantiasa diperhatikan. Namun, di sisi lain aspek bisnis yang menjadi salah satu tujuan operasional rumah sakit juga harus dipertimbangkan. Oleh karena itu, pendekatan pemasaran rumah sakit memiliki penyesuaian dan harus diadaptasi dengan baik dari konsep pemasaran pada dunia bisnis pada umumnya.

Penelitian ini bertujuan untuk memberikan gambaran penyusunan strategi pemasaran bagi rumah sakit, khususnya di Indonesia. Melalui analisis pada salah satu rumah sakit swasta khusus jantung di Jakarta, penelitian ini diharapkan mampu memberikan panduan dan juga inspirasi bagi manajemen rumah sakit di Indonesia dalam mengembangkan strategi pemasaran mereka secara lebih baik dengan merespon kebutuhan pasar secara cepat. Menggunakan pendekatan market-based management, penelitian ini akan memberikan kajian dan analisis pasar, kekuatan internal perusahaan, dan juga matriks portofolio bagi pengembangan bisnis rumah sakit XYZ ke depan. Diharapkan model analisis ini juga bisa dikembangkan pada penelitian lain di berbagai rumah sakit di Indonesia.

\section{Market-Based Management}

Market-based management merupakan sebuah pendekatan penyusunan rencana pemasaran yang merespon kondisi pasar untuk peningkatan perolehan finansial perusahaan (Best, 2013). Dalam bukunya yang berjudul “market-based management: strategis for growing customer value and profitability”, Best (2013) mengungkapkan bahwa sebuah strategi bisnis 
harus didominasi oleh analisis pasar dan kekuatan posisi perusahaan di tengah industri tersebut. Karena itulah konsep market-based management ini diformulasikan dengan harapan perusahaan bisa meningkatkan customer value dan juga profitability dari sisi finansial (Putra \& Maulana, 2018; Dewi dan Darma, 2019).

Dalam merancang sebuah strategi marketing dengan pendekatan market-based management ini, peneliti bisa menggunakan beberapa pilihan strategi ditawarkan sesuai dengan posisi portofolio produk di akhir penghitungan analisis. Konsep strategi tersebut didasarkan pada evaluasi product life cycle (Barksdale \& Harris, 1982; McAfee, 2019) maupun menggunakan pendekatan GE/Mc-Kinsey Portfolio (Amatulli et al., 2011). Dalam penelitian ini, penulis menggunakan pendekatan GE/Mc-Kinsey Portfolio. Dalam portfolio analysis tersebut, peneliti akan bisa menentukan arah strategi marketing yang bisa digunakan untuk perusahaan antara offensive atau defensive strategi. Untuk menentukan pilihan strategi tersebut, maka digunakan dua alat analisis, yaitu Market Attractiveness Index dan Competitive Position Index (Best, 2013).

Market Attractiveness merupakan analisis untuk melihat perkembangan pasar di mana industri tersebut beroperasi. Dalam analisis market attractiveness ini, kita harus memahami beberapa hal yang mempengaruhi perkembangan dan situasi pasar tersebut. Daya tarik pasar dipengaruhi oleh tiga faktor utama yaitu kekuatan pasar (market forces), lingkungan kompetitif (competitive environment), serta akses pasar (market access) (Best, 2013; Adnyana dan Darma, 2015).

Jika daya tarik pasar dilihat dari faktor eksternal, maka competitive position dilihat dari kondisi internal perusahaan. Kekuatan internal yang dimiliki perusahaan menjadi poin penting yang akan dianalisis dalam matrix competitive position tersebut. Tiga faktor kunci dalam analisis internal ini ialah keunikan perusahaan untuk bersaing (differentiation advantage), keunggulan pada biaya (cost advantage), dan keunggulan pada kegiatan marketing (marketing advantage) (Best, 2013). Semakin unggul keunikan bersaing yang dimiliki perusahaan, maka akan semakin kuat modal perusahaan untuk bersaing dengan para competitor (Maulana, 2017; Peteraf \& Bergen, 2003; Krisnamurti dan Darma, 2015).

Hasil analisis daya tarik pasar dan kekuatan internal perusahaan tersebut kemudian diformulasikan ke dalam analisis portfolis. Market Attractiveness berada pada sumbu X, sedangkan competitive position berada pada sumbu Y. Hasil skor penilaian yang merupakan perkalian antara rating dan bobot masing-masing indikator pada matriks tersebut akan menjadi pedoman untuk menentukan posisi perusahaan (Best, 2013). Dalam 9 (Sembilan) kuadaran 
portfolio tersebut, maka akan bisa digambarkan dengan jelas mengenai posisi perusahaan dan pilihan strategi yang hendak digunakan, apakah offensive (strategi menyerang) atau defensive (strategi bertahan) (Amatulli et al., 2011; Best, 2013; Kanten dan Darma, 2017).

Offensive strategy terbagi ke dalam tiga pilihan sub-strategi, yaitu strategi invest to grow (terus bertumbuh), improve position (meningkatkan posisi di pasar), dan enter new market (memasuki pasar baru). Sedangkan defensive strategy terbagi juga ke dalam tiga substrategy, yaitu hold/protect share position (bertahan pada pasar saat ini), optimize/monetize position (mengoptimalkan penjualan pada cakupan pasar saat ini), dan harvest/divest share position (panen penghabisan dari pasar saat ini) (Barksdale \& Harris, 1982; Udo-Imeh et al., 2012).

Pertanyaan besar yang harus dijawab pada penyusunan posisi kompetitif perusahaan tersebut ialah sejauh mana atau sekuat apa sebuah perusahaan mampu untuk menghadapi persaingan di tengah pasar? Untuk mengukur posisi kompetitif tersebut, maka masing-masing komponen pada table market attractiveness dan competitive position di atas akan dituliskan ke dalam sebuah matriks yang akan memberikan penghitungan derajat kepentingannya. Setelah memperoleh skor akhir dari kedua matriks tersebut, langkah selanjutnya ialah menentukan posisi perusahaan pada GE/Mc-Kinsey Portfolio. Portfolio ini menggunakan hasil analisis dari market attractiveness index dan competitive position index sehingga bisa digunakan pada matriks portfolio tersebut (Best, 2013).

\section{METODOLOGI PENELITIAN}

Penelitian ini menggunakan mix method yang menggabungkan penelitian kuantitatif dan kualitatif di dalam analisisnya. Penggunaan dua metode ini dilakukan untuk memberikan kajian komprehensif dari data yang beragam. Pada tahap awal, pengumpulan data secara kualitatif dilakukan dengan studi literatur, analisis dokumen, wawancara, dan observasi. Berbagai metode pengumpulan data tersebut digunakan agar data yang didapatkan bisa mencapai tingkat saturasi yang optimal (Sekaran \& Bougie, 2011). Data yang diperoleh kemudian dianalisis dan diinterpretasi dengan dua pendekatan yaitu content analysis dan context analysis. Content analysis digunakan untuk memberikan interpretasi dari makna kata dan kalimat yang dikumpulkan. Sedangkan context analysis memberikan interpretasi terhadap konteks pemakaian kata atau kalimat dalam analisis tersebut (Wahyuni, 2019). Kedua alat analysis ini digunakan untuk mendapatkan hasil interpretasi yang konsisten dalam penelitian, terutama untuk memastikan validitas dan reliabilitas konstruk penelitian yang dibangun 
(Maxwell \& Reybold, 2015).

Untuk mendapatkan data internal, penulis melakukan wawancara dengan tiga orang pimpinan rumah sakit XYZ, yaitu direktur operasional, manajer pengembangan bisnis, dan juga manajer marketing. Selain itu, penulis juga melakukan observasi pelaksanaan kegiatan promosi rumah sakit, serta melakukan studi dokumen untuk mengetahui tingkat kepuasan pasien di rumah sakit tersebut. Selain itu, untuk mendapatkan data analisis eksternal (market attractiveness), penulis melakukan survey pasar, wawancara ahli (expert judgement), dan juga melakukan analisis perbandingan dengan dua rumah sakit sejenis lainnya di Jakarta.

Setelah data dikumpulkan dan diinterpretasi berdasarkan kode analisis, kemudian data tersebut dikelompokkan ke dalam beberapa komponen matriks market attractiveness dan juga matriks competitive position. Seluruh data dikelompokkan sesuai dengan kategori analisis tersebut untuk kemudian dilakukan analisis kuantitatif dengan pemberian bobot dan skor tiap kategori data pada matriks tersebut.

Masing-masing komponen di dalam matriks tersebut diberikan bobot berbeda yang mengindikasikan tingkat urgensi dan kepentingan dari faktor tersebut dibandingkan dengan faktor lain di dalam analisis. Pemberian bobot untuk masing-masing komponen matriks market attractiveness dan competitive position tersebut mengikuti angka yang sudah disarankan di dalam kerangka analisis market-based management tersebut (Best, 2013).

Setelah penghitungan bobot dan skor untuk masing-masing analisis market attractiveness dan competitive position dilakukan, kemudian angka tersebut diintegrasikan dengan GE/McKinsey portfolio matrix yang akan menentukan posisi strategi yang akan diimplementasikan, apakah offensive atau defensive strategy. Barulah kemudian, setelah indeks posisi strategi ditemukan, peneliti melanjutkan narasi dan implementasi strategi yang bisa dikembangkan sesuai dengan arahan stratgi portfolio tersebut.

\section{PEMBAHASAN}

Untuk pembahasan market attractiveness, hal pertama yang penulis lakukan ialah dengan menganalisis daya tarik pasar pelayanan jantung. Dari data yang dirilis oleh World Health Organization (WHO) pada tahun 2015 silam, 17,5 juta dari 58 juta kematian di dunia disebabkan oleh penyakit jantung dan pembuluh darah. Dari seluruh angka tersebut, penyebab kematian antara lain disebabkan oleh serangan jantung (7.6 juta), stroke (5.7 juta), dan selebihnya disebabkan oleh penyakit jantung dan pembuluh darah (4.2 juta penduduk) (WHO, 2015). WHO juga memprediksi bahwa kematian yang disebabkan oleh penyakit jantung dan 
pembuluh darah akan meningkat hingga angka 20 juta kasus kematian pada beberapa tahun mendatang.

Penyakit jantung dan pembuluh darah juga menjadi ancaman besar bagi sebagian besar masyarakat di Indonesia. Menurut data hasil Riset Kesehatan Dasar (Riskesdas) Kementerian Kesehatan Republik Indonesia tahun 2013, angka penyakit jantung koroner dan gagal jantung di Indonesia mencapai angka 1,8\% dari jumlah penduduk. Dari data tersebut juga bisa dilihat bahwa penyakit stroke yang menjadi bagian dari penyakit pembuluh darah telah mencapai angka 12,1\% dari total penduduk (Badan Penelitian dan Pengembangan Kesehatan, 2013). Jika dilihat dari hasil riset Kementerian Kesehatan tersebut, dari seluruh wilayah di Indonesia, DKI Jakarta menempati posisi kedua dengan penderita penyakit Jantung Koroner tertinggi di Indonesia yaitu sebanyak $0,7 \%$. Posisi teratas dimiliki oleh Sulawesi Tengah dengan angka $0,8 \%$.

Dari data di atas dapat digambarkan bahwa permintaan pasar terhadap kebutuhan layanan kesehatan jantung di Indonesia, khususnya Jakarta masih tergolong tinggi. Jika dikalkulasikan, market demand penderita penyakit jantung koroner di Jakarta bisa dikalkulasikan dengan asumsi bahwa jumlah penduduk Jakarta 11.000 .000 orang, penderita jantung coroner $0,7 \%$ dari total penduduk, dan biaya pengobatan jantung koroner (biaya ratarata) Rp. 50.000.000. Maka angka market demand bisa diperoleh dengan menghitung angka penderita $(0,7 \%$ X 11.000 .000$)$ dikalikan dengan rata-rata biaya pengobatan jantung sebesar Rp. 50.000.000, sehingga total kebutuhan pasar terhadap pelayanan penyait jantung ialah sebesar Rp. 3.850.000.000.000.

Angka kebutuhan pasar untuk penanganan penyakit jantung di Jakarta masih terbilang cukup tinggi dan memberikan peluang pasar yang signifikan bagi pengembangan bisnis pelayanan kesehatan jantung, khususnya untuk rumah sakit khusus penanganan jantung di Jakarta dan sekitarnya. Oleh karena itu, skor untuk market attractiveness relative lebih tinggi dibandingkan nilai competitive position yang akan dijelaskan pada table selanjutnya.

Analisis kedua pada komponen competitive position ialah mengenai kebutuhan konsumen dan tingkat persaingan di pasar. Guna mengetahui lebih lanjut tentang selera pasar dan perilaku konsumen dan calon konsumen, penulis melakukan survey persepsi publik terhadap komponen bauran pemasaran (marketing mix) rumah sakit khusus jantung di Jakarta. Survey dilakukan terhadap 76 responden yang dipiih secara purposive sampling, yakni responden dewasa (di atas 20 tahun), memiliki pengeluaran di atas Rp. 1.000 .000 per bulan, dan tinggal di kawasan Jakarta dan sekitarnya. Masing-masing responden diberikan kuesioner 
yang berisi pernyataan dan pilihan jawaban terhadap komponen product, place, price, promotion, process, people, dan physical evidence (Kotler, 2011). Responden diberi pilihan jawaban sesuai dengan skala likert (1-4), yakni terdiri dari pilihan "sangat tidak setuju, "tidak setuju", "setuju", dan "sangat setuju". Berikut ringkasan hasil survey tentang persepsi publik terhadap komponen marketing mix RS khusus jantung di Jakarta:

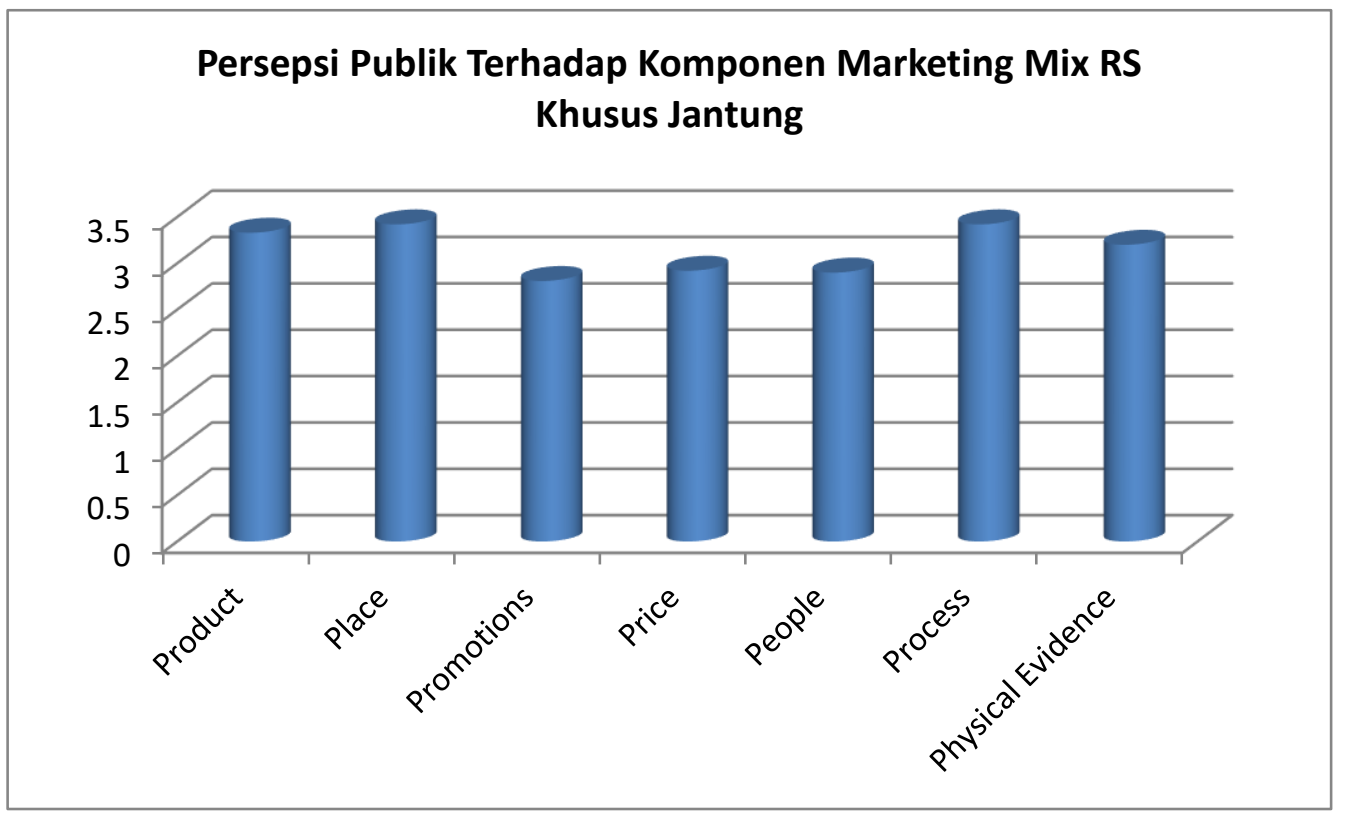

Gambar 1.

Grafik persepsi publik terhadap marketing mix rumah sakit

Dari grafik di atas bisa dilihat bahwa komponen marketing mix yang paling dominan berpengaruh pada persepsi masyarakat ialah komponen process. Bagi masyarakat, proses pelayanan dan penanganan pasien di rumah sakit menjadi pertimbangan utama dalam memilih rumah sakit. Hal ini terbukti dengan hasil survey yang menempatkan komponen proses sebagai komponen terpenting bagi marketing mix rumah sakit khusus jantung di Jakarta. Komponen terpenting kedua ialah tentang lokasi rumah sakit. Semakin strategis lokasi sebuah rumah sakit maka akan semakin menarik perhatian dan menjadi pilihan bagi masyarakat. Selain itu, sarana dan prasarana penunjang juga menjadi pertimbangan penting bagi masyarakat untuk menentukan pilihan pada satu rumah sakit. Kelancaran lalu lintas, keberadaan transportasi umum, toko, tempat makan, dan beberapa prasarana lainnya yang menjadi faktor pertimbangan bagi masyarakat.

Hal menarik dari hasil survey ini ialah tentang posisi promotion, price, dan people yang memperoleh nilai yang lebih rendah dari komponen marketing mix lainnya. Walau masih 
masuk dalam kategori "Baik" (range nilai 2.0 - 3.0), akan tetapi perolehan nilai rata-rata yang berada di bawah komponen marketing mix lainnya menjadi sebuah fakta yang menarik. Bisa disimpulkan bahwa bagi masyarakat yang berpartisipasi dalam survey ini, promosi rumah sakit tidak begitu berpengaruh signifikan bagi marketing RS khusus jantung. Secara umum dari hasil survey ini, publik menilai bahwa rumah sakit tidak perlu beriklan di media massa dan lebih baik melakukan promosi melalui kegiatan edukasi kesehatan secara langsung.

\section{Market Attractiveness Index}

Setelah semua data diperoleh dan dianalisis sesuai dengan kode dan kategorisasinya masing-masing, selanjutnya data tersebut diolah dengan matriks market attractiveness untuk mengetahui angka atau posisi indeks daya tarik industri pelayanan kesehatan jantung di Jakarta. Berikut adalah tabel market attractiveness tersebut:

Tabel 1. Market Attractiveness Index

\begin{tabular}{|c|c|c|c|c|}
\hline very unattractive unattractive & $\begin{array}{c}\text { Somewhat } \\
\text { Unattractive }\end{array}$ & $\begin{array}{l}\text { Somewhat } \\
\text { attractive }\end{array}$ & Attractive & Very Attractive \\
\hline 20 & 40 & 60 & 80 & 100 \\
\hline Market forces & \multirow{2}{*}{$\begin{array}{c}\text { Relative } \\
\text { Importance }\end{array}$} & \multirow{2}{*}{$\begin{array}{l}\text { Attractiveness } \\
\text { rating }\end{array}$} & & \multirow{2}{*}{$\begin{array}{l}\text { Attractiveness } \\
\text { Score }\end{array}$} \\
\hline Factor Importance: $30 \%$ & & & & \\
\hline Market Size & $40 \%$ & 40 & & 16 \\
\hline Growth Rate & $30 \%$ & 60 & & 18 \\
\hline \multirow[t]{2}{*}{ Buyer Power } & $30 \%$ & 80 & & 24 \\
\hline & total: $100 \%$ & & Total $=$ & 58 \\
\hline Competitive Environment & \multirow{2}{*}{$\begin{array}{c}\text { Relative } \\
\text { Importance }\end{array}$} & \multirow{2}{*}{$\begin{array}{l}\text { Attractiveness } \\
\text { rating }\end{array}$} & & \multirow{2}{*}{$\begin{array}{l}\text { Attractiveness } \\
\text { Score }\end{array}$} \\
\hline Factor Importance: $30 \%$ & & & & \\
\hline Price Rivalry & $40 \%$ & 60 & & 24 \\
\hline Ease of Competitor Entry & $35 \%$ & 40 & & 14 \\
\hline \multirow[t]{2}{*}{ Number of Competitors } & $35 \%$ & 60 & & 21 \\
\hline & total: $100 \%$ & & Total $=$ & 59 \\
\hline Market Access & \multirow{2}{*}{$\begin{array}{c}\text { Relative } \\
\text { Importance }\end{array}$} & \multirow{2}{*}{$\begin{array}{l}\text { Attractiveness } \\
\text { rating }\end{array}$} & & \multirow{2}{*}{$\begin{array}{l}\text { Attractiveness } \\
\text { Score }\end{array}$} \\
\hline Factor Importance: $40 \%$ & & & & \\
\hline Customer Familiarity & $40 \%$ & 60 & & 24 \\
\hline Channel Access & $30 \%$ & 80 & & 24 \\
\hline \multirow[t]{2}{*}{ Sales/Service requirements } & $30 \%$ & 60 & & 18 \\
\hline & total: $100 \%$ & & Total $=$ & 66 \\
\hline
\end{tabular}

Sumber: olahan penulis

Market Attractiveness Index $=(30 \%$ x 58) $+(30 \%$ x 59) $+(40 \%$ x 66 $)=\mathbf{6 1 , 5}$

Pada tabel di atas, kita bisa melihat bahwa 3 (tiga) komponen utama market 
attractiveness index memiliki persentase factor of importance yang berbeda-beda. Persentase ini menggambarkan derajat kepentingan satu faktor untuk mempengaruhi penilaian matriks secara kseluruhan. Market Forces atau kekuatan pasar memiliki persentase kepentingan sebesar 30\%, sama pentingnya dengan competitive environment yang juga memiliki persentase $30 \%$. Kedua komponen ini memiliki peran yang sama besar untuk menentukan kekuatan pasar di dalam bisnis rumah sakit khusus jantung.

Sedangkan, komponen ketiga, market access memili persentase yang agak lebih besar, yaitu $40 \%$. Nilai ini penulis berikan karena akses merupakan hal terpenting bagi sebuah bisnis untuk mempertemukan antara perusahaan sebagai penyedia barang dan jasa, dengan masyarakat sebagai konsumen atau pembeli. Karena itu, di sini penulis menilai bahwa peran market access untuk memperkenalkan kekuatan bisnis rumah sakit XYZ kepada masyarakat harus memiliki porsi nilai yang lebih besar dibandingkan dengan komponen yang lainnya.

Sementara itu, dalam kategori market force, distribusi nilai relative importance masingmasing faktor hampir terdistribusi dengan seimbang. Hanya market size yang memiliki angka persentase lebih besar dibandingkan dengan dua faktor lainnya. Karena itu, penulis memberi nilai 50 untuk market size. NIlai 60 penulis berikan untuk menilai perkembangan growth rate bisnis rumah sakit jantung di Jakarta, berdasarkan data perbandingan dari tiga rumah sakit. Angka bed occupancy ratio (BOR) dari ketiga rumah sakit tersebut menunjukkan adanya peningkatan yang cukup signifikan, walaupun masih belum ideal. Begitupula untuk buyer power, penulis memberikan skor 70 mengingat daya beli masyarakat Indonesia semakin meningkat seiring bertambahnya jumlah kelas menengah ke atas di kota besar di Indonesia.

Dalam menyikapi persaingan bisnis di antara penyedia layanan kesehatan Jantung di Jakarta, rumah sakit XYZ cukup memiliki kekuatan dan keunggulan bersaing yang bisa menjadi kekuatan. Keunggulan tersebut bisa dilihat dari faktor harga dan tarif pelayanan, kemungkinan pendatang baru, dan jumlah kompetitor yang ada di dalam pasar saat ini. Walau hasil penelitian menyatakan bahwa untuk pengobatan penyakit jantung, masyarakat cenderung tidak memeprsoalkan harga. Tetapi untuk menarik daya tarik dan minat masyarakat, perbedaan harga dan tarif layanan yang cukup signifikan akan memberi andil dalam pemilihan rumah sakit. Karena itu, penulis memberi bobot $40 \%$ bagi faktor price rivalry. Sedangkan untuk kedua faktor lainnya, yakni ease of new competitor dan number of competitors, penulis berasumsi bahwa kekuatan dan pengaruh yang hampir sama besar. Karena itu, bobot 35\% untuk kedua faktor ini penulis berikan tanpa membedakan angka yang cukup signifikan.

Salah satu kekuatan rumah sakit XYZ ialah komponen harga yang transparan dan 
akuntabel sehingga bisa menerapkan cost efficiency dalam setiap tindakan medis. Hal ini berdampak pada penetapan tariff yang dilakukan oleh manajemen. Hingga saat ini, tarif pelayanan kesehatan yang diberlakukan di JHC cukup kompetitif dengan rumah sakit lain bahkan beberapa komponen biaya justru lebih murahdari kompetitor. Karena itu, nilai 70 untuk kekuatan price rivary penulis berikan.

Sedangkan untuk dua faktor lainnya, yaitu ease of competitor entry dan number of competitors penulis berikan bobot yang sama yakni 35\%. Kedua faktor tersebut dipandang memiliki peran dan tantangan yang hampir sama bagi rumah sakit XYZ saat ini. Industri rumah sakit jantung memiliki rintangan yang cukup tinggi bagi pendatang baru, baik tantangan di jumlah investasi, tenaga kerja, begitu pula tantangan di regulasi yang juga sangat mengikat. Karena itu, tidak heran jika jumlah kompetitor dalam bisnis ini tidak begitu banyak. Saat ini saja, kurang dari lima rumah sakit khusus jantung yang beroperasi di Jakarta dan sekitarnya.

Market access memiliki nilai factor importance yang lebih besar dibandingkan dengan dua komponen market attractiveness lainnya. Sejalan dengan ketentuan yang dituliskan oleh Best (2013), penulis juga menilai derajat kepentingan market access lebih tinggi dibandingkan dengan komponen lainnya di dalam bisnis rumah sakit ini. Dalam menyusun sebuah strategi marketing rumah sakit, penulis memandang bahwa akses calon pasien terhadap materi marketing lebih utama dibandingkan dengan komponen marketing lainnya. Karena itu, nilai $40 \%$ untuk komponen ini penulis pandang sebagai sebuah angka yang cukup menggambarkan derajat kepentingannya tersebut. Mengenai bobot ketiga faktor yang ada di market access, penulis distribusi secara merata. Untuk faktor customer familiarty, bobot angka yang penulis berikan ialah $40 \%$. Hal ini didasarkan pada hasil survey yang penulis lakukan bahwa masyarakat akan memilih rumah sakit yang benar-benar telah mereka kenal reputasi dan citra pelayanannya. Namun, untuk saat ini, rumah sakit XYZ masih belum begitu dikenal oleh masyarakat luas. Walau nilai brand awareness relative lebih tinggi disbanding beberapa competitor lainnya, akan tetapi angka tersebut masih cukup jauh di bawah market leader. Oleh karena itu angka 60 penulis berikan untuk tingkat customer familiarty rumah sakit XYZ.

Namun, untuk penilaian channel access dan sales/service requirements, penulis memberikan bobot persentase dan skor penilaian yang sama. Bobot kedua faktor ini ialah 30\% maisng-masing dengan angka skor 70. Rumah sakit XYZ sudah cukup attractive dalam menyediakan channel access bisnis mereka dengan berlokasi di "city of healthcare" yang didukung sarana dan prasarana transportasi yang tidak sulit. Begitu pula untuk nilai service requirements, Rumah Sakit XYZ telah terbukti memberikan service yang berkualitas bagi para 
pasien mereka dengan angka kepuasan pasien yang cukup tinggi.

\section{Competitive Position Index}

Penghitungan competitive position index tidak jauh berbeda dengan penghitungan market attractiveness index. Walau kedua tabel tersebut hampir menggunakan cara penghitungan yang relatif sama, namun untuk penggunaan istilah dan nama-nama faktor penunjang tetap memiliki perbedaan. Berikut analisis Competitive Position Index rumah sakit XYZ Jakarta:

Tabel 2. Competitive Position Index

\begin{tabular}{|c|c|c|c|c|}
\hline $\begin{array}{l}\text { Considerably } \\
\text { behind }\end{array}$ & $\begin{array}{l}\text { Somewhat } \\
\text { Behind }\end{array}$ & $\begin{array}{c}\text { Somewhat } \\
\text { ahead }\end{array}$ & $\begin{array}{l}\text { Clearly } \\
\text { ahead }\end{array}$ & $\begin{array}{c}\text { Considerably } \\
\text { ahead }\end{array}$ \\
\hline 20 & 40 & 60 & 80 & 100 \\
\hline $\begin{array}{l}\text { Differentiation Advantage } \\
\text { Factor Importance: } 40 \%\end{array}$ & $\begin{array}{c}\text { Relative } \\
\text { Importance }\end{array}$ & $\begin{array}{l}\text { Attractiveness } \\
\text { rating }\end{array}$ & & $\begin{array}{l}\text { Attractiveness } \\
\text { Score }\end{array}$ \\
\hline Product Quality & $35 \%$ & 80 & & 28 \\
\hline Service Quality & $35 \%$ & 80 & & 28 \\
\hline \multirow[t]{2}{*}{ Brand Image/Reputation } & $30 \%$ & 40 & & 12 \\
\hline & total: $100 \%$ & & total $=$ & 68 \\
\hline $\begin{array}{l}\text { Cost Advantage } \\
\text { Factor Importance: } 20 \%\end{array}$ & $\begin{array}{c}\text { Relative } \\
\text { Importance }\end{array}$ & $\begin{array}{l}\text { Attractiveness } \\
\text { rating }\end{array}$ & & $\begin{array}{l}\text { Attractiveness } \\
\text { Score }\end{array}$ \\
\hline Cost of Goods Sold & $40 \%$ & 40 & & 16 \\
\hline Marketing and Sales expenses & $35 \%$ & 40 & & 14 \\
\hline \multirow[t]{2}{*}{ Overhead expenses } & $35 \%$ & 60 & & 21 \\
\hline & total: $100 \%$ & & total $=$ & 51 \\
\hline $\begin{array}{l}\text { Marketing Advantage } \\
\text { Factor Importance: } 40 \%\end{array}$ & $\begin{array}{c}\text { Relative } \\
\text { Importance }\end{array}$ & $\begin{array}{l}\text { Attractiveness } \\
\text { rating }\end{array}$ & & $\begin{array}{l}\text { Attractiveness } \\
\text { Score }\end{array}$ \\
\hline Market Share & $40 \%$ & 40 & & 16 \\
\hline Brand Awareness & $40 \%$ & 60 & & 24 \\
\hline \multirow[t]{2}{*}{ Distribution } & $20 \%$ & 80 & & 16 \\
\hline & total: $100 \%$ & & total $=$ & 56 \\
\hline
\end{tabular}

Sumber: olahan penulis

Competitive Position Index $=(40 \% \times 68)+(20 \% \times 51)+(40 \% \times 56)=\mathbf{5 9 , 8}$

Satu hal yang menarik dari tabel di atas ialah mengenai proporsi nilai factor importance untuk ketiga komponen tersebut. Penulis memberikan porsi nilai yang sama untuk komponen Differentiation Advantage dan Marketing Advantage sebesar 40\%. Hal ini karena kedua komponen tersebut memiliki peran besar dalam meningkatkan posisi kompetitif perusahaan di tengah pasar. Sedangkan, dalam bisnis rumah sakit, manajemen tidak bisa terlalu banyak mengatur komposisi biaya (COGS) karena keterikatan pada penyalur alat dan bahan medis, regulasi pemerintah, dan juga bergantung pada image dan kualitas pelayanan. Karena itu, 
penulis memberi porsi nilai $20 \%$ untuk komponen Cost Advantage ini.

Komponen pertama dari competitive position index ialah faktor-faktor keuntungan pembeda atau differentiation advantage. Komponen ini terdiri dari faktor product quality dan service quality. Penulis memberi bobot persentase yang sama untuk kedua faktor ini, yaitu 35\%. Penulis memandang bahwa dalam bisnis pelayanan kesehatan, fungsi product quality berbanding lurus dengan service quality (Avrianti, 2016). Karena itu, derajat kepentingan untuk kedua faktor tersebut harus sebanding dan seimbang.

Sedangkan untuk skor kinerja Rumah Sakit XYZ terhadap faktor-faktor tersebut, penulis memberi angka 70 untuk product quality dan 80 untuk service quality. Hasil survey kepuasan pasien menunjukkan bahwa tingkat kepuasan pasien terhadap service quality Rumah Sakit JHC memang lebih tinggi dibandingkan dengan product quality yang disajikan. Selain itu, dalam bisnis jasa, kekuatan service atau pelayanan konsumen akan sangat berpengaruh terhadap kesuksesan dan kelancaran bisnis.

Sementara itu, komponen biaya layanan kesehatan di Rumah Sakit XYZ tersebut terdiri dari banyak faktor. Mulai dari biaya medis habis pakai, imbalan jasa dokter, biaya alat medis, serta biaya administrasi. Semua komponen biaya tersebut memiliki ketentuan tersendiri sesuai dengan aturan pemerintah dan juga kebijakan rumah sakit. Oleh karena itu, beban biaya pelayanan atau cost of good sold (COGS) memiliki porsi nilai yang cukup besar dibandingkan dengan kedua faktor yang lain. Penulis memberi bobot $40 \%$ untuk COGS dan masing-masing $35 \%$ untuk marketing expenses dan overhead expenses. Kedua faktor tersebut penulis anggap sebagai faktor penunjang dalam menentukan cost differentiation untuk industri rumah sakit.

Mengenai rating nilai yang penulis berikan, skor 60 untuk COGS merupakan angka yang menurut penulis cukup sesuai dengan kondisi rumah sakit saat ini. Komponen biaya yang kompleks dan bargaining position manajemen yang cukup rendah dalam mengambil kebijakan membuat Rumah Sakit XYZ tidak bisa merancang lebih jauh strategi penetapan biaya operasional rumah sakit. Apalagi, saat ini rumah sakit sudah mengikat kontrak kerja untuk 5 tahun mendatang dengan beberapa supplier farmasi yang memiliki komponen harga jual obat dan bahan medis yang relative lebih tinggi dibanding harga pasaran.

Sementara itu, nilai 40 penulis berikan untuk marketing expenses. Hal ini karena minimnya anggaran yang diberikan untuk kegiatan marketing. Memang, manajemen belum membuat anggaran khusus untuk marketing karena divisi tersebut belum memiliki kerangka kerja dan rencana strategis untuk kegiatan marketing rumah sakit. Nilai 70 penulis berikan untuk faktor overhead expenses karena manajemen sudah cukup mampu mengelola kebutuhan 
biaya tambahan dari biaya pokok operasional. Menurut keterangan Direktur Keuangan Rumah Sakit XYZ, saat ini kendala terbesar dalam mengatur keuangan rumah sakit terletak pada komponen biaya medis yang cukup tinggi. Sedangkan untuk biaya penunjang berupa insentif dokter, gaji perawat dan karyawan, serta biaya administrasi sudah bisa disesuaikan dengan tingkat kebutuhan perusahaan dan juga mempertimbangkan tingkat daya beli pasien.

Selanjutnya, komponen terakhir dari competitive position ialah komponen marketing advantage. Sama halnya dengan beberapa komponen sebelumnya, komponen ini memiliki tiga faktor yang menjadi penentu bagi keunggulan marketing. Faktor pertama dan kedua ialah market share yang penulis beri bobot $40 \%$ dan brand awareness yang juga penulis beri bobot $40 \%$. Kedua faktor tersebut memiliki peran yang sangat besar dalam menentukan keunggulan marketing perusahaan layanan kesehatan. Sedangkan faktor ketiga, distribution penulis beri bobot persentase sebesar 20\%. Hal ini karena faktor ini tidak begitu berpengaruh dalam bisnis rumah sakit (Hariyanti \& Rosyidah, 2013; Karmawan, 2016). Distribusi produk di bisnis rumah sakit tidak berpengaruh besar karena proses jual beli atau tukar menukar jasa sebagian besar hanya terjadi di lingkungan rumah sakit. Karena itu, proses distribusi untuk bisnis rumah sakit tidak akan berpengaruh signifikan dalam menentukan marketing advantage perusahaan. Mengenai skor penilaian masing-masing faktor, penulis memberi nilai 60 untuk market share Rumah Sakit XYZ. Hingga saat ini, belum ada penghitungan market share yang valid tentang industri rumah sakit jantung di Jakarta maupun Indonesia secara keseluruhan. Penghitungan yang paling memungkinkan hanyalah berupah kalkulasi Bed Occupancy Ratio yang dimiliki oleh setiap rumah sakit. Perbandingan BOR ini menjadi pertimbangan penulis untuk memberi angka 60 bagi skor market share Rumah Sakit XYZ untuk saat ini.

Sedangkan untuk nilai brand awareness, berdasarkan hasil penelitian yang telah dilakukan oleh manajemen, tingkat brand awareness rumah sakit XYZ sudah cukup baik walau belum mencapai angka yang ideal. Karena itu, penulis memberi skor 70 untuk capaian brand awareness tersebut. Terakhir, untuk penilaian faktor distribusi, penulis memberi skor 80 karena proses distribusi pelayanan yang dilakukan di lingkungan rumah sakit sudah cukup baik. Melalui metode pelayanan 90 minutes door to balloon, Rumah Sakit XYZ berkomitmen untuk melayani setiap pasien secara cepat, tepat, dan efisien.

\section{GE/MC Kinsey Portfolio Matrix}

Hasil Market Attractiveness Index dan Competitive position index tersebut selanjutnya diintegrasikan ke dalam GE/Mc Kinsey Portfolio Matrix. Titik pertemuan kedua garis lurus 
dari angka indeks tersebut akan menentukan posisi portfolio perusahaan di dalam matriks. Posisi tersebut juga akan menjadi landasan untuk mengambil keputusan dan memilih strategi apa yang paling cocok dan sesuai untuk diimplementasikan oleh perusahaan sesuai dengan hasil analisis yang telah dilakukan sebelumnya. Untuk lebih jelasnya, berikut penulis gambarkan GE/Mc Kinsey Portfolio Matrix Rumah Sakit XYZ:
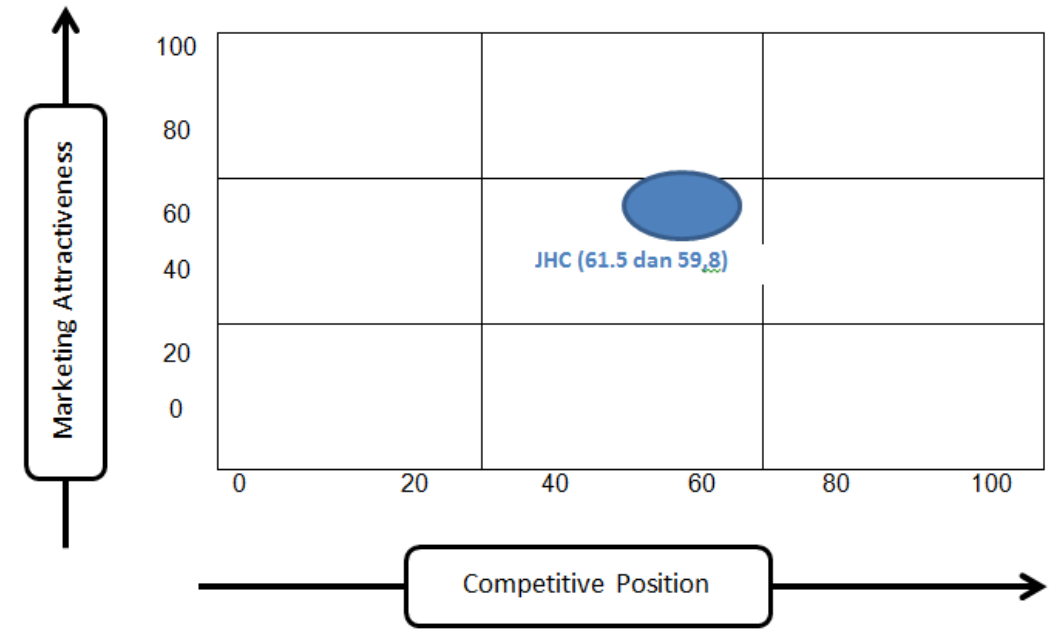

Gambar 2. GE/Mckinsey Portfolio Matrix untuk Rumah Sakit XYZ Source: Adaptasi dari Best (2013)

Dari matriks di atas dapat terlihat bahwa posisi portfolio bisnis Rumah Sakit XYZ terletak pada kuadran 5 dengan titik koordinat 59,8 (Competitive position) dan 61,5 (Market attractiveness). Posisi tersebut menggambarkan bahwa langkah strategi JHC berada pada dua pilihan, yaitu Offensive atau Defensive strategi (Best, 2013). Kedua pilihan strategi tersebut bisa menjadi pertimbangan bagi manajemen untuk menentukan arah bisnis ke depan dan juga menentukan arah strategi marketing yang akan digunakan.

Namun, melihat skor nilai matriks yang didapat dari analisis market attractiveness dan competitive position sebelumnya, maka penulis melihat bahwa kecenderungan nilai bagi Rumah Sakit XYZ untuk saat ini mengarah pada implementasi strategi offensive. Menurut Best (2013), ada tiga core strategy atau strategi inti di dalam offensive strategy. Ketiga strategi inti tersebut memiliki objective spesifik masing-masing. 


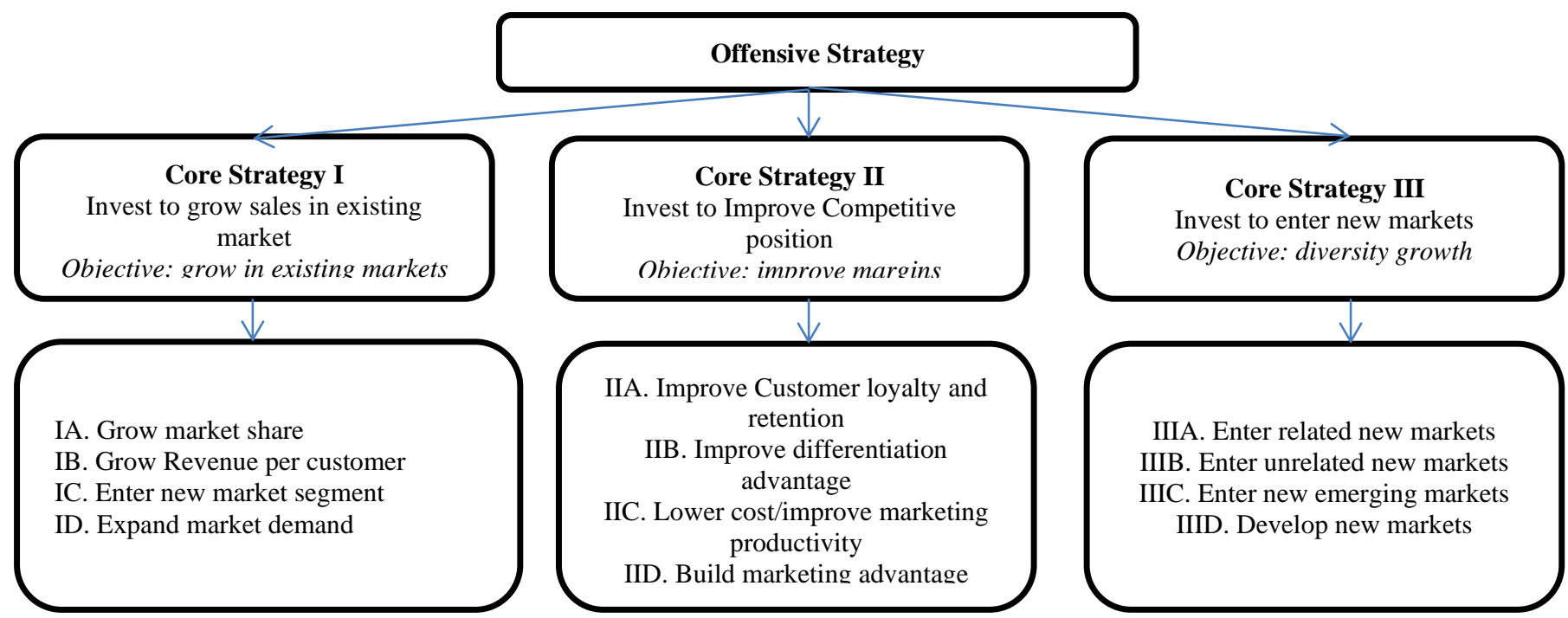

Gambar 3. Alternatif Pilihan Strategi pada Offensive Strategy

Source: Best (2013)

Dari gambar 3 di atas bisa dilihat bahwa Offensive strategy memiliki objective dan pendekatan pelaksanaannya masing-masing. Core strategy I berbicara mengenai peningkatan penjualan dan memperluas pangsa pasar. Core strategy II berbicara mengenai peningkatan profit dan minimallisir biaya operasional. Sedangkan, core strategy III berbicara mengenai upaya ekspansi ke target pasar baru yang lebih luas. Jika ketiga core strategy tersebut dikaitkan dengan visi misi Rumah Sakit XYZ saat ini, maka penulis menympulkan bahwa manajemen belum bisa mengimplementasikan seluruh core strategy dari pilihan offensive strategy tersebut. Hal ini terutama berkaitan dengan core strategy III yang memiliki sasaran untuk memperluas pangsa pasar dengan melakukan ekspansi ke target pasar yang lebih luas. Bagi perusahaan yang baru beberapa tahun beroperasi dan belum memiliki evaluasi menyeluruh terhadap kinerja periode awal pendiriannya, ekspansi pasar bukanlah sebuah pilihan yang strategis bagi perusahaan. Karena itu, core strategy III belum bisa dilaksanakan untuk periode perencanaan marketing strategis ini.

Sedangkan untuk Core Strategy $I$ dan II, penulis menilai bahwa untuk mengimplementasikan kedua core strategy tersebut adalah suatu hal yang mungkin saja bisa diimplementasikan oleh manajemen Rumah Sakit XYZ untuk periode 3 tahun mendatang. Melihat kinerja rumah sakit pada beberapa tahun beroperasi ini dan dari hasil analisis situasi yang telah penulis lakukan, implementasi terhadap core strategy I dan II akan bisa meningkatkan performa kerja dan juga bisa mengatasi tantangan marketing yang sedang dihadapi oleh manajemen saat ini. Namun, sebagai sebuah rumah sakit yang relative baru, 
pemilihan core strategy II belum bisa difokuskan pada periode pertama strategi marketing ini. Dalam kurun 3 tahun mendatang, manajemen akan lebih baik jika mengedepankan segala upaya untuk mempertahankan posisi perusahaan di tengah pasar dan semakin memperluas jangkauan pasar.

Hal ini bisa dinilai sebagai sebuah langkah investasi. Fokus manajemen pada tahuntahun awal beroperasinya rumah sakit ini ialah untuk meningkatkan pangsa pasar, meningkatkan okupansi rumah sakit, dan mempertahankan pendapatan sesuai target awal rumah sakit. Jika hal ini bisa dicapai dengan baik pada periode strategi ini, maka selanjutnya manajemen bisa meningkatkan level strategi mereka menjadi strategi peningkatan profit dan minimalisasi cost operasional. Oleh karena itu, pada perancangan marketing strategis ini, penulis akan menggunakan rancangan core strategy I dari offensive strategy. Pemilihan strategi ini akan bisa meningkatkan kinerja perusahaan dan diharapkan juga akan mampu menjawab tantangan dan mengatasi berbagai masalah marketing yang sedang dihadapi Rumah Sakit XYZ.

Terdapat empat pilihan strategi pada core strategy I, namun berdasarkan skor nilai pada table market attractiveness dan competitive position, penulis memilih dua strategi terakhir sebagai strategi marketing pilihan. Kedua strategi itu ialah strategi IC; enter new market segment, dan strategi ID; expand market demand. Dua strategi yang dipilih tersebut penulis nilai sebagai langkah marketing strategis yang paling cocok dengan kondisi manajemen Rumah Sakit XYZ untuk saat ini. Salah satu marketing objective mereka ialah untuk meningkatkan permintaan pasar serta mampu memasuki segmentasi pasar yang baru di kelas menengah ke bawah. Dua objectif tersebut akan bisa dijawab dengan menggunakan core strategi IC dan ID tersebut.

Sedangkan strategi IA dan IB merupakan langkah strategis yang belum bisa diterapkan oleh manajemen untuk saat ini. Mengenai peningkatan market share, hingga saat ini, belum ada data yang lengkap dan kredibel mengenai penjelasan market share industri rumah sakit jantung di Jakarta. Sehingga, jika strategi ini diterapkan, maka manajemen nantinya akan mengalami kesulitan untuk mengukur dan mengevalusi implementasi strategi. Mengenai strategi untuk meningkatkan revenue per customer, penulis menilai hal itu juga masih belum diterapkan oleh manajemen selama periode marketing strategis ini. Komponen biaya operasional dan perolehan keuntungan yang dimiliki oleh rumah sakit masih belum bersifat baku dan final. Manajemen masih mengalami kesulitan untuk memasang standar yang jelas untuk menetapkan persentase biaya dan keuntungan secara umum, sehingga untuk mengukur 
peningkatan revenue per customer masih sering dilakukan secara manual. Selain itu, fokus kegiatan marketing untuk 3 tahun ke depan masih tertuju pada upaya untuk meningkatkan perolehan revenue rumah sakit sebesar Rp. 4 - 6 Milyar per bulan dengan cara meningkatkan okupansi. Core strategy IB ini akan lebih cocok diiimplementasikan jika kegiatan operasional rumah sakit sudah mulai stabil, okupansi rumah sakit sudah ideal, dan manajemen sudah memiliki formula khusus untuk menerapkan price strategy. Oleh karena itu, penulis tidak merekomendasikan strategi IA dan IB dalam rancangan strategi ini.

\section{PENUTUP}

Untuk implementasi strategi terpilih yang sudah didapatkan dari hasil analisis, maka penulis menyarankan beberapa program pemasaran yang bisa diimplementasikan oleh pihak rumah sakit. Pertama, ialah pentingnya membuat divisi komunikasi pemasaran atau Corporate \& Marketing Communitaion untuk meningkatkan citra positif rumah sakit di mata pasien dan juga calon konsumen. Selain itu, literasi yang baik terhadap penanganan penyakit jantung juga harus menjadi prioritas program promosi secara preventif yang harus digencarkan oleh rumah sakit. Karena itu, urgensi pendirian divisi ini menjadi semakin penting dan harus memiliki rencana kerja yang jelas dan terukur.

Kedua ialah optimasi tim sales force agar lebih gencar melakukan kegiatan penjualan atau direct selling dengan menyasar pasar B2B (Kotler, 2011). Program executive medical check-up bisa menjadi alternative layanan yang bisa ditawarkan kepada pihak korporat sebagai bagian dari program promosi kesehatan di lingkungan pekerjaan masing-masing. Rumah Sakit XYZ bisa menjadi vendor penyedia jasa tersebut dengan fokus pada pelayanan yang bak, exclusive, dan tentunya dengan harga yang premium. Oleh karena itu, manajemen rumah sakit harus membuat satu tim khusus yang bisa melakukan koordinasi dalam pelaksanaan program.

Ketiga ialah mengenai pembaharuan media promosi. Dari hasil penilaian pada matriks analisis sebelumnya, nilai awareness dan image Rumah Sakit XYZ masih belum optimal dan harus bisa ditingkatkan. Salah satu faktor penilaiannya ialah karena komponen promosi yang kurang menarik, dan juga ketersediaan akses publik yang masih terbatas. Karena itu, manajemen perlu melakukan revitalisasi seluruh konten promosi dan desain komunikasi visual agar penetrasi pasar bisa dilakukan secara lebih optimal.

Terakhir ialah penerapan strategi push \& Pull Strategy yang baik oleh divisi Corporate \& Marketing Communication. Push strategy cenderung untuk memberikan dorongan kepada rekanan rumah sakit agar bisa turut serta meningkatkan okupansi pelayanan, misalnya dengan 
bekerjasama dengan berbagai perusahaan asuransi dan penjamin kesehatan. Sedangkan pull strategy ialah dengan melakukan komunikasi pemasaran secara langsung kepada target konsumen (Amudavi et al., 2007; Cook et al., 2007). Kedua implementasi strategy ini memiliki sasaran yang berbeda, sehingga sales force yang terlibat juga harus dari tim yang berbeda pula.

Itulah beberapa alternative strategi yang bisa dilakukan oleh manajemen Rumah Sakit XYZ dalam meningkatkan pendapatan dan juga sasaran strategi pemasaran mereka. Walau analisis ini masih perlu dilanjutkan dengan rancangan teknis pelaksanaan program pemasaran, namun dari analisis ini penulis bisa memberikan gambaran kepada manajemen mengenai kondisi eksternal dan internal perusahaan sebelum melakukan kegiatan pemasaran. Semoga kerangka penelitian ini bisa diadopasi dan diimplementasikan oleh penelitian selanjutnya dalam menyusun rencana strategis untuk program pemasaran di rumah sakit.

\section{Acknowledgement}

Penulis mengucapkan terima kasih kepada Manajemen Rumah Sakit XYZ, Dosen Sekolah Tinggi Manajemen PPM, dan juga para narasumber dan pihak lainnya yang telah berpartisipasi demi kelancaran penelitian ini. 


\section{DAFTAR PUSTAKA}

Adnyana, R., and Darma, G.S. (2015). Strategi Marketing Mix, Yield Management, Customer Satisfaction and Occupancy Rate, Jurnal Manajemen \& Bisnis, 12 (1): 92-115.

Amatulli, C., Caputo, T., \& Guido, G. (2011). Strategic Analysis Through The General Electric/Mckinsey Matrix: An Application To The Italian Fashion Industry, International Journal Of Business And Management, 6 (5): 61-75. https://Doi.Org/10.5539/Ijbm.V6n5p61

Amudavi, D., Khan, Z., \& Pickett, J. (2007). Enhancing The Push-Pull Strategy, Leisa Magazine.

Avrianti, I. (2016). Planning Matrix Sebagai Upaya Peningkatan Mutu Pelayanan Rawat Inap Di Rumah Sakit Umum Bhakti Rahayu Surabaya, Jurnal Administrasi Kesehatan Indonesia, 4 (2): 163. https://Doi.Org/10.20473/Jaki.V4i2.2016.163-175

Badan Penelitian Dan Pengembangan Kesehatan. (2013). Riset Kesehatan Dasar 2013.

Barksdale, H. C., \& Harris, C. E. (1982). Portfolio Analysis And The Product Life Cycle, Long Range Planning. https://Doi.Org/10.1016/0024-6301(82)90010-3

Best, R. J. (2013). Market-Based Management (Internatio). Pearson.

Burhanudin, M. N. (2019). Mulawarman Menggunakan Metode Quantitative Strategic Planning Matrix ( Qspm ). 5 (1), 1-6.

Cook, S. M., Khan, Z. R., \& Pickett, J. A. (2007). The Use Of Push-Pull Strategies In Integrated Pest Management, Annual Review Of Entomology. https://Doi.Org/10.1146/Annurev.Ento.52.110405.091407

Dewi, N. K. Y. W., \& Sri Darma, G. (2019). Strategi Investasi \& Manajemen Resiko Rumah Sakit Swasta Di Bali, Jurnal Manajemen Bisnis, $16 \quad$ (2): 110. https://Doi.Org/10.38043/Jmb.V16i2.2044

Dewi, M.V.K., and Darma, G.S. (2019). The Role of Marketing \& Competitive Intelligence In Industrial Revolution 4.0, Jurnal Manajemen \& Bisnis, 16 (1): 1-12.

Hariyanti, E., \& Rosyidah. (2013). Analisis Strategi Pemasaran Pelayanan Skin Medical Center Di Rumah Sakit Pku Muhammadiyah Yogyakarta, Jurnal Kesehatan Masyarakat (Journal Of Public Health), 4 (2): 76-82. Https://Doi.Org/10.12928/Kesmas.V4i2.1094

Karmawan, B. (2016). Penyusunan Rencana Strategis Rumah Sakit Pertamina Jaya Tahun 2017-2022, Jurnal Arsi, 2 (2): 115-126.

Kosala, D. T. I. A., \& Maradona, A. F. (2019). Can Government Hospital Survive In The Era Of National Health Insurance?, Jurnal Manajemen Bisnis, 16 (2): 50. 
https://Doi.Org/10.38043/Jmb.V16i2.2040

Kotler, P. (2011). Reinventing Marketing To Manage The Environmental Imperative, Journal Of Marketing. https://Doi.Org/10.1509/Jmkg.75.4.132

Krisnamurti, M.B., and Darma, G.S. (2015). Strategi Diferensiasi Produk dan Jasa di Industri Digital Printing, Jurnal Manajemen \& Bisnis, 12 (1): 122-139.

Kanten, I.K., and Darma, G.S. (2017). Consumer Behaviour, Marketing Strategy, Customer Satisfaction, and Business Performance, Jurnal Manajemen \& Bisnis, 14 (2): 143-165.

Maulana, N. (2017). The Influence Of Barosok Trading System On Ethical Business Behavior In The Husbandry Sector In West Sumatera, Journal Of Advanced Research In Social Sciences And Humanities, 2 (2): 131-138. Https://Doi.Org/10.26500/Jarssh-02-20170208

Maxwell, J. A., \& Reybold, L. E. (2015). Qualitative Research. In International Encyclopedia Of The Social \& Behavioral Sciences: Second Edition. Https://Doi.Org/10.1016/B978-008-097086-8.10558-6

Mcafee, R. P. (2019). Product Life Cycle, Competitive Solutions. Https://Doi.Org/10.2307/J.Ctvcm4hsb.8

Pandiangan, B., \& Damanik, H. (2019). Strategi Pemasaran Rawat Inap Layanan Non-BPJS Pasca Program Layanan BPJS Di Rumah Sakit Murni Teguh Medan, Jurnal Mutiara Manajemen, 4 (2): 379-391. Http://114.7.97.221/Index.Php/Jmm/Article/View/1065

Peteraf, M. A., \& Bergen, M. E. (2003). Scanning Dynamic Competitive Landscapes: A Market-Based And Resource-Based Framework, Strategic Management Journal, 24 (10 Spec Iss.): 1027-1041. https://Doi.Org/10.1002/Smj.325

Puspitasari, N. B., Amnes, S., \& Thoatillah, K. (2016). Perancangan Strategi Pemasaran Pada Rumah Sakit Nasional Diponegoro Semarang, Perancangan Strategi Pemasaran Pada Rumah Sakit Nasional Diponegoro Semarang, 5 (3): 184-194.

Putra, G. S. A., \& Maulana, N. (2018). Strategi Meningkatkan Daya Saing Industri Kreatif Indonesia: Studi Kasus Pengembangan Klaster Industri Tamansari Bogor, 10 (2).

Sekaran, U., \& Bougie, R. (2011). Business Research Methods: A Skill-Building Approach. In Wiley. https://Doi.Org/http://As.Wiley.Com/Wileycda/Wileytitle/Productcd111994225x.Html\#

Subianto, A. (2016). Analisis Swot Tentang Strategi Pemasaran Dalam Upaya Meningkatkan Kunjungan Pasien Di Klinik Bunda.

Setyawati, T., and Darma, G.S. (2018). Efektifkah Experiential Marketing di Sebuah Rumah 
Sakit ?, Jurnal Manajemen \& Bisnis, 15 (1): 160-175.

Udo-Imeh, P., Edet, W., \& Anani, R. (2012). Portfolio Analysis Models: A Review, European Journal Of Business And ....

Vikandi, B., Sonny Sm Laksono, \& Imam Baihakki. (2019). Strategi Pemasaran Rumah Sakit Di Era Jaminan Kesehatan Nasional (JKN) Study RSM Siti Khodijh Kediri Belingga, Revitalisasi: Jurnal Ilmu Manajemen, 8 (2): 180-184.

Wahyuni, S. (2019). Qualitative Research Method : Theory And Practice 3rd Edition (3rd Ed., Issue 3rd Edition). Salemba Empat.

WHO. (2015). Media Centre - Cardiovascular Diseases (CVDS), Fact Sheet N. 317. https://Doi.Org/10.1148/Radiol.13122128 